\title{
APLIKASI DIAGNOSA PENYAKIT TUBERCULOSIS MENGGUNAKAN METODE CERTAINTY FACTOR BERBASIS ANDROID
}

\author{
Hilda Rismaya Hidayat', Wildan Wiguna² \\ 1 Universitas Adhirajasa Reswara Sanjaya \\ e-mail: hilris31@gmail.com \\ ${ }^{2}$ Universitas Adhirajasa Reswara Sanjaya \\ e-mail: wildan@ars.ac.id
}

\begin{abstract}
Abstrak
Tuberkulosis adalah penyakit yang disebabkan oleh bakteri Mycobacterium Tuberculosis. Penularan penyakit ini, umumnya terjadi melalui droplet atau percikan cairan seperti batuk atau bersin. Penyakit Tuberkulosis memiliki dua jenis yaitu Tuberkulosis Paru dan Tuberkulosis Ekstra Paru. Pada penyakit Tuberkulosis Ekstra Paru memiliki berbagai macam jenis diantaranya Tuberkulosis Tulang Belakang, Tuberkulosis Kelamin, Tuberkulosis Ginjal, dan Tuberkulosis Usus. Penyakit Tuberkulosis dapat menyebabkan kematian jika terlambat dalam penanganan dan kurangnya pengetahuan mengenai penyakit Tuberkulosis. Klinik Pratama Mitramedik Arcamanik merupakan sarana kesehatan yang salah satu layanannya yaitu menyediakan pemeriksaaan terhadap pasien Tuberkulosis. Dari semua permasalahan yang ada dapat diselesaikan menggunakan suatu sistem pakar. Salah satu metode yang digunakan pada sistem pakar adalah Certainty Factor. Metode tersebut mampu menghitung nilai kepastian gejala untuk menghasilkan diagnosa dari berbagai jenis penyakit Tuberkulosis. Dalam memudahkan perhitungan Certainty Factor dapat digunakan aplikasi berbasis mobile yang berjalan pada platform Android. Sehingga tujuan dari penelitian ini yaitu untuk menerapkan metode Certainty Factor berbasis mobile menggunakan pemograman Android di Klinik Pratama Mitramedik Arcamanik. Hasil dari penelitian ini yaitu memberikan infomasi tentang penyakit Tuberkulosis Tulang Belakang, Kelamin, Ginjal, dan Usus, sehingga membantu memepercepat penanganan medis dalam mendiagnosa penyakit Tuberkulosis secara dini. Kemudian aplikasi diagnosa penyakit Tuberkulosis berbasis mobile berhasil dibangun menggunakan pemrograman Android.

Kata Kunci: Sistem Pakar, Aplikasi Android, Penyakit Tuberkulosis, Metode Certainty Factor
\end{abstract}

\begin{abstract}
Tuberculosis is a disease caused by the bacteria Mycobacterium Tuberculosis. Transmission of this disease, generally occurs through droplets or splashes of fluids such as coughing or sneezing. Tuberculosis has two types, namely pulmonary Tuberculosis and Extra-Lung Tuberculosis. Extra-Pulmonary Tuberculosis has various types including spinal Tuberculosis, Genital Tuberculosis, Kidney Tuberculosis, and Intestinal Tuberculosis. Tuberculosis can cause death if late treatment and lack of knowledge about Tuberculosis. Klinik Pratama Mitramedik Arcamanik is a health facility which one of the services is providing examinations of Tuberculosis patients. Of all the problems that exist can be solved using an expert system. One method used in expert systems is Certainty Factor. This method is able to calculate the certainty value of symptom to produce a diagnosis of various types of Tuberculosis. To simplify the calculation of Certainty Factors, mobile-based applications that run on the Android platform can be used. So that, the purpose of this research is to apply the mobile-based Certainty Factor method using Android programming in the Klinik Pratama Mitramedik Arcamanik. The results of this research are to provide information about Tuberculosis of the Spine, Genitals, Kidneys, and Intestines, thus helping to accelerate early medical treatment in Tuberculosis diagnosis. Then the mobile-based Tuberculosis diagnosis application was successfully built using Android programming.
\end{abstract}

Keywords: Expert System, Tuberculosis Disease, Certainty Factor Method, Android Application 


\section{Pendahuluan}

Tuberculosis atau biasa dikenal dengan TBC adalah penyakit infeksi menular yang disebabkan oleh bakteri mycobacterium Tuberculosis. Penyakit ini paling sering menyerang paru-paru walaupun pada sepertiga kasus menyerang organ tubuh lain dan ditularkan melalui nuclei droplet lewat udara dari orang ke orang. TBC juga merupakan penyakit tertua yang diketahui menyerang manusia (Lestyaningrum \& Anardani, 2017).

Tuberculosis merupakan salah satu penyakit yang mematikan di dunia. Sebagian besar kasus kematian Tuberculosis terjadi diantara laki-laki yaitu sebanyak 5,4 juta jiwa pada anak. Jumlah kematian Tuberculosis ini sebenarnya dapat dikurangi mengingat bahwa sebagian besar dapat dicegah jika orang dapat mengjangkau layanan kesehatan untuk mendapatkan diagnosis dan pengobatan yang tepat. Tuberculosis merupakan penyakit yang mudah menular melalui udara pada saat batuk, bersin ataupun menyanyi, pasien menyebarkan kuman keudara dalam bentuk percikan dahak yang mampu menghasilkan 3000 percikan dahak (Bangun, 2019).

Klinik Pratama Mitramedik Arcamanik merupakan sarana kesehatan yang salah satu layanannya yaitu menyediakan pemeriksaaan terhadap pasien Tuberculosis. Klinik ini didirikan dengan tujuan untuk membantu pemerintah dalam bidang kesehatan, serta memberikan pelayanan kesehatan yang baik bagi masyarakat sekitar. Klinik Pratama Mitramedik Arcamanik juga sudah bekerjasama dengan Badan Penyelenggara Jaminan Sosial (BPJS) hingga saat ini.

Dari hasil observasi yang telah dilakukan di Klinik Pratama Mitramedik Arcamanik, terdapat beberapa permasalahan dalam melakukan diagnosa penyakit TBC. Permasalahan tersebut seperti minimnya kesadaran dan pengetahuan masyarakan mengenai penyakit TBC. Hal ini dapat menyebabkan keterlambatan dalam penanganannya dan mengakibatkan penyakit tersebut semakin serius sehingga dapat menghilangan nyawa seseorang. Kemudian kurangnya fasilitas yang dapat membantu tenaga medis dalam memeriksa pasien untuk mendiagnosa TBC secara dini. Dari beberapa permasalahan yang ada dikarenakan belum tersedianya suatu aplikasi bergerak untuk mendiagnosa TBC yang dapat digunakan atau diimplementasikan di Klinik Pratama Mitramedik Arcamanik.

Suatu diagnosa penyakit dapat dioptimalkan menggunakan sistem pakar dengan metode Certainty Factor untuk menunjukan nilai kepastian dari suatu fakta yang belum pasti (Girsang \& Fahmi, 2019). Terdapat beberapa penelitian yang membahas tentang metode Certainty Factor, diantaranya penelitian tentang sistem pakar untuk deteksi penyakit Tuberculosis Paru. Pada penelitian tersebut membandingkan hasil deteksi sistem pakar dengan hasil perhitungan manual yang dapat memberikan hasil yang sama (Surya et al., 2018). Kemudian terdapat juga penelitian sistem pakar mendiagnosa infeksi saluran pernapasan akut (ISPA) menggunakan metode Certainty Factor. Dengan hasil penerapan metode Certainty Factor dalam sistem pakar mampu menampilkan presentase penyakit dan hasil keyakinan user setelah proses konsultasi (Laksono et al., 2016).

Sistem pakar adalah sistem komputer yang dapat meniru kemampuan seorang pakar. Sistem ini bekerja untuk mengadopsi pengetahuan manusia kekomputer yang menggabungkan dasar pengetahuan dengan sistem inferensi untuk menggantikan fungsi seorang pakar dalam menyelesaikan suatu masalah (Fanny et al., 2017). Sedangkan metode Certainty Factor merupakan sebuah perhitungan tingkat kepastian terhadap kesimpulan yang diperoleh dan dihitung berdasarkan nilai probabilitas penyakit karena adanya evident gejala. Dengan menggunakan metode Certainty Factor akan diperoleh hasil diagnosis penyakit berdasarkan nilai CF tertinggi yang didapatkan dari hasil perhitungan dari beberapa gejala yang dialami penderita (Fanny et al., 2017).

\begin{tabular}{lrr} 
Suatu sistem & pakar dengan \\
metode Certainty & $\begin{array}{r}\text { Factor dapat } \\
\text { Fach }\end{array}$ \\
diimplementasikan & menggunakan \\
perangkat mobile. & \multicolumn{2}{c}{ Salah satu }
\end{tabular} perangkat mobile. Salah satu
pengembangan aplikasi yang berjalan pada perangkat mobile yaitu menggunakan pemrograman Android (Septiana, 2016). Sistem operasi Android bersifat open source sehingga mudah dikembangkan 
dan dioptimalkan pada suatu sistem pakar (Paramitha et al., 2019). Android menyediakan platform sumber terbuka bagi para pengembang agar dapat menciptakan aplikasi sesuai dengan yang diinginkan (Putra et al., 2016).

Aplikasi yang akan dibangun nantinya berjalan menggunakan smartphone Android dengan menampilkan informasi serta gejala-gejala yang dapat dipilih oleh pemakai. Sehingga aplikasi ini berguna dalam mendapatkan hasil apakah pengguna terjangkit TBC atau tidak yang bermanfaat bagi penggunanya. Dari permasalahan yang telah dipaparkan sebelumnya, maka tujuan dari penelitian ini yaitu untuk membangun aplikasi mobile diagnosa penyakit Tuberculosis dengan menerapkan metode Certainty Factor di Klinik Pratama Mitramedik Arcamanik.

\section{Metode Penelitian \\ Teknik Pengumpulan Data}

Guna mendapatkan data primer maupun sekunder penunjang teori pelengkap dalam penyusunan penelitian ini digunakan beberapa metode pengumpulan data sebagai berikut:

1. Observasi

Merupakan metode pengumpulan data dengan cara meninjau secara langsung pada penyakit Tuberculosis yang akan diteliti. Penulis menemui bagian pengurus Klinik Pratama Mitramedik. Hasil observasi menunjukan bahwa pada Klinik Pratama Mitramedik Arcamanik belum terdapat sistem pakar untuk mendiagnosa penyakit Tuberculosis.

2. Wawancara,

Proses wawancara dilakukan langsung dengan dokter melalui metode tanyajawab dengan materi pertanyaan dan diskusi seputar penyakit Tuberculosis baik dari faktor penyebab, gejala, pencegahan dan pengobatannya. Wawancara dilakukan secara langsung dengan Dr. H. Sudrajat Alibasyah yang merupakan salah satu dokter pada Klinik Pratama Mitramedik Arcamanik.

3. Studi Pustaka

Mempelajari beberapa jurnal maupun buku-buku yang menunjang dan berkaitan dengan pembangunan aplikasi diagnosa penyakit Tuberculosis dengan metode Certainty factor menggunakan pemrograman Android.

\section{Metode Pengembangan Aplikasi}

Pada penyusunan laporan ini penulis menggunakan model Waterfall yang merupakan salah satu metode pengembangan perangkat lunak yang paling populer dan dianggap sebagai model siklus hidup berurutan linier untuk pengembangan sistem (Behl et al., 2019). Model Waterfall yang terbagi menjadi beberapa tahapan prosedur atau langkah-langkah dalam pembuatan aplikasi diagnosa penyakit Tuberculosis (Wiguna \& Alawiyah, 2019) diantaranya:

1. Analisis

Analisis dilakukan dengan pengumpulan data penyakit Tuberculosis untuk memperoleh data-data yang dibutuhkan. Guna menentukan solusi pengembangan sistem.

2. Desain Sistem

Desain sistem menciptakan serangkaian spesifikasi teknis yang lengkap agar dapat digunakan untuk membangun aplikasi. Pada tahap ini didefinisikan kebutuhan sistem yang terkait dengan perancangan aplikasi diagnosa penyakit Tuberculosis yang akan dibangun. Tahap perancangan ini meliputi rancangan database menggunakan Entity

Relationship Diagram (ERD) dan software architecture menggunakan diagram Unified Modeling Language (UML).

3. Implementasi

Tahap implementasi adalah proses konversi desain sistem ke dalam kodekode program. Penulisan kode program menggunakan Java sebagai controller dan XML dalam membuat layout dari antarmuka pengguna. Pemograman dilakukan menggunakan Android Studio dengan basis data SQLite.

4. Pengujian

Beberapa jenis pengujian harus dilakukan sebelum aplikasi siap untuk digunakan. Teknik pengujian yang dilakukan terhadap aplikasi diagnosa penyakit Tuberculosis pada penelitian ini yaitu menggunakan white-box testing. Pengujian tersebut digunakan untuk mengetahui kompleksitas siklomatis dari gambaran flowchart dalam mengakses aplikasi tersebut.

5. Support

Tahap akhir pengembangan aplikasi diagnosa penyakit Tuberculosis yang melibatkan perubahan sistem untuk 
membuatnya lebih berguna dalam mencapai tujuan pengguna dan organisasi.

\section{Certainty Factor}

Certainty factor atau biasa disingkat CF adalah nilai untuk mengukur keyakinan pakar. CF diperkenalkan oleh Shortliffe Buchanan dalam pembuatan sistem pakar MYCIN yang merupakan nilai parameter klinis yang diberikan MYCIN untuk menunjukan besarnya kepercayaan (Andriani, 2016). Secara umum, rule direpresentasikan dalam bentuk sebagai berikut:

$$
C F(H, E)=M B(H, E)-M D(H, E)
$$

Keterangan:

$$
\begin{aligned}
& \mathrm{CF}(\mathrm{H}, \mathrm{E}) \text { : Faktor kepastian } \\
& \text { MB }(\mathrm{H}, \mathrm{E}) \text { : Kepercayaan terhadap } \\
& \text { hipotesis } \mathrm{H} \text {, jika diberikan } \\
& \text { evidence } \mathrm{E} \text {. } \\
& M D(H, E) \text { : Ketidakpercayaan terhadap } \\
& \text { hipotesis } \mathrm{H} \text {, jika diberikan } \\
& \text { evidence } \mathrm{E} \text {. }
\end{aligned}
$$

\section{Hasil dan Pembahasan}

Pada penulisan laporan penelitian ini penulis mengambil beberapa materi atau teori dari berbagai sumber. Hal ini dimaksudkan untuk mempermudah penulis dalam mengerjakan laporan penelitian. Dengan materi yang tepat diharapkan dapat menghasilkan aplikasi sistem pakar yang baik dan bermanfaat. Berikut penulis paparkan materi yang menjadi landasan dalam penulisan ini.

\subsection{Analisis}

\section{A. Studi Kasus}

Tuberculosis (TBC) adalah penyakit yang menjadi salah satu masalah besar di bidang kesehatan yang disebabkan oleh bakteri Mycobacterium Tuberculosis. Penularannya melalui aerosol atau droplet nuclei. Penyakit ini dapat diobati hingga sembuh dan dapat dicegah (Mertaniasih, 2019). Beberapa jenis penyakit TBC yaitu:

1. Tuberkulosis Tulang Belakang

Tuberkulosis Tulang Belakang adalah bentuk TBC yang merusak. TBC tulang belakang sering terjadi pada anak-anak dan remaja. Adanya penghancuran sendi utama pada tulang belakang dan badan ruas tulang belakang yang tak beraturan berdekatan, runtuhnya elemen tulang belakang, irisan anterior yang mengarah pada bengkoknya tulang belakang dan penonjolan pada tulang belakang (Acton, 2012). Gejala-gejala dari penderita Tuberkulosis Tulang Belakang dapat diuraikan sebagai berikut:

a. Demam

b. Berkeringat dimalam hari

c. Penurunan berat badan

d. Anoreksia (Gangguan Makan)

e. Sakit punggung yang terlokalisir

f. Memiliki posisi tubuh yang kaku dan tegak

g. Tulang belakang menjadi bungkuk (kifosis)

h. Pembengkakan pada tulang punggung

i. Muncul menjolan pada pangkal paha

2. Tuberkulosis Kelamin

Tuberkulosis Kelamin umumnya disebabkan oleh mycobacterium

Tuberculosis hominis. Pada wanita, Tuberkulosis Kelamin hampir selalu sekunder yang diakibatkan oleh lesi primer di paru-paru, walaupun keterlibatan peradangan pada lapisan tipis dinding perut dan kelenjar getah bening dapat mendahului TB kelamin (Keith, 2012). Berikut adalah gejala dari penderita Tuberkulosis Kelamin:
a. Demam
b. Penurunan berat badan
c. Kelelahan
d. Nyeri pinggul
e. Siklus menstruasi tidak teratur
f. Keputihan yang terdapat bercak darah
g. Keputihan berlebihan
h. Pendarahan setelah berhubungan seksual
i. Infertilitas (tidak subur)

3. Tuberkulosis Ginjal

Tuberkulosis Ginjal adalah infeksi ginjal yang disebabkan oleh mycobacterium $s p$. Terjadi Sekitar 10\% dari TBC diluar paru. TBC ginjal dapat terjadi pada infeksi akut, penyebaran TBC paru aktif secara hematogen atau reaktivasi infeksi laten (Chang, 2014). Berikut ini gejala dari penderita Tuberkulosis Ginjal:
a. Penurunan berat badan
b. Kelelahan
c. Sakit pinggang
d. Kencing berdarah
e. Demam parah
f. Sering buang air kecil
g. Penurunan nafsu makan 
4. Tuberkulosis Usus

Tuberkulosis Usus sebagian besar disebabkan oleh mycobacterium Tuberculosis. TBC usus disebabkan oleh mycrobacterium bovis yaitu suatu organisme yang ditemukan dalam produk susu sapi yang tidak dipasteurisasi (Hamer, 2010). Sebagian besar pasien penderita TBC usus tidak menunjukan gejala, tetapi keluhan yang paling umum dari Tuberkulosis Usus yaitu:
a. Demam
b. Penurunan berat badan
c. Diare
d. Muncul darah pada tinja
e. Nyeri perut
f. Muntah

\section{B. Tabel Pakar}

Dalam penyakit Tuberculosis terdapat beberapa gejala yang dapat membantu mendiagnosa. Pada penyakit Tuberculosis penulis hanya membatasi sebanyak 4 penyakit. Dari 4 penyakit 25 gejala yang dapat terasa. Berikut data penyakit dan data gejala beserta kodenya.

Pada Tabel 1 menampilkan daftar jenis penyakit Tuberculosis (TBC).

Tabel 1. Penyakit Tuberculosis

\begin{tabular}{|c|c|}
\hline Kode & Nama Penyakit \\
\hline P1 & Tuberkulosis Tulang Belakang \\
\hline P2 & Tuberkulosis Kelamin \\
\hline P3 & Tuberkulosis Ginjal \\
\hline P4 & Tuberkulosis Usus \\
\hline
\end{tabular}

Pada Tabel 2 menampilkan daftar gejala dari penyakit Tuberculosis (TBC).

Tabel 2. Gejala Tuberculosis

\begin{tabular}{|c|l|}
\hline Kode & \multicolumn{1}{|c|}{ Nama Gejala } \\
\hline G01 & Demam \\
\hline G02 & Berkeringat dimalam hari \\
\hline G03 & Penurunan berat badan \\
\hline G04 & Anoreksia (Gangguan Makan) \\
\hline G05 & $\begin{array}{l}\text { Sakit Punggung yang } \\
\text { terlokalisir }\end{array}$ \\
\hline G06 & $\begin{array}{l}\text { Memiliki posisi tubuh yang } \\
\text { kaku dan tegak }\end{array}$ \\
\hline G07 & $\begin{array}{l}\text { Tulang belakang menjadi } \\
\text { bungkuk (kifosis) }\end{array}$ \\
\hline G08 & $\begin{array}{l}\text { Pembengkakan pada tulang } \\
\text { punggung }\end{array}$ \\
\hline G09 & $\begin{array}{l}\text { Muncul benjolan pada pangkal } \\
\text { paha menyerupai hernia }\end{array}$ \\
\hline G10 & Kelelahan \\
\hline
\end{tabular}

\begin{tabular}{|l|l|}
\hline G11 & Nyeri pinggul \\
\hline G12 & Siklus menstruasi tidak teratur \\
\hline G13 & $\begin{array}{l}\text { Keputihan yang terdapat } \\
\text { bercak darah }\end{array}$ \\
\hline G14 & Keputihan berlebihan \\
\hline G15 & $\begin{array}{l}\text { Pendarahan setelah } \\
\text { berhubungan seksual }\end{array}$ \\
\hline G16 & Infertilitas (tidak subur) \\
\hline G17 & Kencing berdarah \\
\hline G18 & Demam parah \\
\hline G19 & Sering buang air kecil \\
\hline G20 & Penurunan nafsu makan \\
\hline G21 & Sakit pinggang \\
\hline G22 & Diare \\
\hline G23 & Muncul darah pada tinja \\
\hline G24 & Nyeri perut \\
\hline G25 & Muntah \\
\hline & \\
\hline
\end{tabular}

Pada Tabel 3 terdapat beberapa jenis penyakit Tuberculosis yang memiliki gejala yang sama. Untuk memudahkan dalam pencariannya, maka penulis menandainya menggunakan simbol $\mathrm{V}$.

Tabel 3. Gejala dan Penyakit TBC

\begin{tabular}{|c|c|c|c|c|}
\hline Kode & P01 & P02 & P03 & P04 \\
\hline G01 & V & V & & V \\
\hline G02 & V & & & \\
\hline G03 & V & V & V & V \\
\hline G04 & V & & & \\
\hline G05 & V & & & \\
\hline G06 & V & & & \\
\hline G07 & V & & & \\
\hline G08 & V & & & \\
\hline G09 & V & & & \\
\hline G10 & & V & V & \\
\hline G11 & & V & & \\
\hline G12 & & V & & \\
\hline G13 & & V & & \\
\hline G14 & & V & & \\
\hline G15 & & V & & \\
\hline G16 & & V & & \\
\hline G17 & & & V & \\
\hline G18 & & & V & \\
\hline G19 & & & V & \\
\hline G20 & & & V & \\
\hline G21 & & & V & \\
\hline G22 & & & & V \\
\hline G23 & & & & V \\
\hline
\end{tabular}




\begin{tabular}{|c|l|l|l|l|}
\hline G24 & & & & V \\
\hline G25 & & & & V \\
\hline
\end{tabular}

\section{Rules Sistem Pakar}

Pada sistem pakar dalam menentukan jenis penyakit Tuberculosis ini terdapat aturan-aturan atau rules beserta perhitungannya menggunakan metode Certainty Factor. Berikut ini merupakan contoh kasus terdapat seorang pasien yang menderita gejala-gejala Antara lain:

1. Demam (G01, MB 0,7 dan MD 0,3)

2. Berkeringat dimalam Hari (G02, MB 0,8 dan MD 0,2)

3. Penurunan Nafsu Makan (G20, MB 0,8 dan MD 0,2)

4. Diare (G22, MB 0,6 dan MD 0,4)

Dari data yang dipilih tersebut maka akan dilakukan perhitungannya menggunakan metode Certainty Factor dengan langkah-langkah penyelesaiannya yang dapat diuraikan sebagai berikut:

a. Penyakit TBC Tulang Belakang (P1) G01

$$
\begin{array}{ll}
\text { Mbl } & : 0,7 \\
\text { Mdl } & : 0,3
\end{array}
$$

G02

$$
\begin{aligned}
\text { Mbb } & : 0,8 \\
\text { Mdb } & : 0,2 \\
\text { Mbs } & =M b l+(M b b *(1-M b l)) \\
& =0,7+\left(0,8^{*}(1-0,7)\right) \\
& =0,94 \\
\text { Mds } & =M d l+(M d b *(1-M d l)) \\
& =0,3+(0,2 *(1-0,3) \\
& =0,44
\end{aligned}
$$

Cf Hasil Mbs - Mds $=0,94-0,44$

$$
=0.5 * 100 \%
$$$$
=50 \%
$$

b. Penyakit TBC Kelamin (P2)

G01

$$
\begin{aligned}
\text { Mbl } & : 0,7 \\
\text { Mdl } & : 0,3 \\
\text { Mbb } & : 0,7 \\
\text { Mdb } & : 0,3 \\
\text { Mbs } & =M b l+(M b b *(1-M b l)) \\
& =0,7+\left(0,7^{*}(1-0,7)\right) \\
& =0,3+\left(0,3^{*}(1-0,3)\right) \\
& =0,91 \\
\text { Mds } & =M d l+(M d b *(1-M d l)) \\
& =0,3+\left(0,3^{*}(1-0,3)\right. \\
& =0,51
\end{aligned}
$$

$$
\begin{aligned}
\text { Cf Hasil Mbs - Mds } & =0,91-0,51 \\
& =0.4 * 100 \% \\
& =40 \%
\end{aligned}
$$

c. Penyakit TBC Ginjal (P3)

$$
\text { G20 }
$$

$$
\begin{aligned}
\text { Mbl } & : 0,8 \\
\text { Mdl } & : 0,2 \\
\text { Mbb } & : 0,8 \\
\text { Mdb } & : 0,2 \\
\text { Mds } & =M d l+(M d b *(1-M d l)) \\
& =0,2+\left(0,2^{*}(1-0,2)\right. \\
& =0,36
\end{aligned}
$$

Cf Hasil Mbs - Mds $=0,96-0,36$

$$
\begin{aligned}
& =0.6 * 100 \% \\
& =60 \%
\end{aligned}
$$

d. Penyakit TBC Usus (P4)

G01

$$
\begin{aligned}
\text { Mbl } & : 0,7 \\
\text { Mdl } & : 0,3 \\
\text { G22 } & \\
\text { Mbb } & : 0,6 \\
\text { Mdb } & : 0,4 \\
\text { Mbs } & =\text { Mbl +(Mbb * }(1-\mathrm{Mbl})) \\
& =0,7+\left(0,6^{*}(1-0,7)\right) \\
& =0,88 \\
\text { Mds } & =\text { Mdl }+\left(M_{d b}^{*}(1-M d l)\right) \\
& =0,3+\left(0,4^{*}(1-0,3)\right. \\
& =0,58
\end{aligned}
$$

Dari hasil perhitungan tersebut kemungkinan User menderita penyakit TBC Ginjal sebesar $60 \%$.

\section{Use Case Diagram}

Digambarkan use case diagram sesuai dengan yang terkait pada proses bisnis utama sistem dari kebutuhan aplikasi diagnosa penyakit Tuberculosis yang akan dikembangkan sebagai berikut:

1. Use Case Diagram User Interaksi antara user dengan aplikasi mobile yang akan dibangun tersebut digambarkan use case diagram user yang dapat dilihat pada Gambar 1.

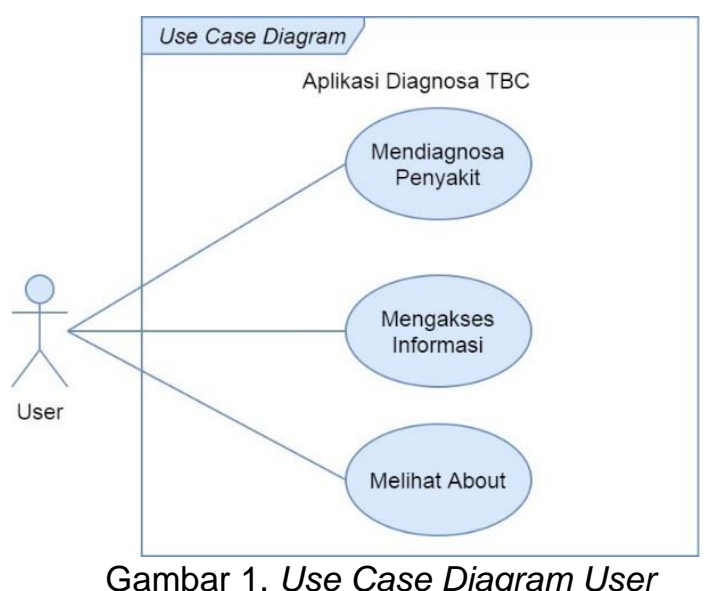

Pada Gambar 1 terdapat beberapa fungsionalitas aplikasi diagnosa penyakit Tuberculosis yaitu: 
a. User dapat melakukan konsultasi atau mendiagnosa penyakit.

b. User mengakses halaman informasi.

c. User mengakses halaman about.

2. Use Case Diagram Admin

Interaksi antara aktor admin dengan aplikasi diagnosa penyakit Tuberculosis dapat dilihat pada Gambar 2.

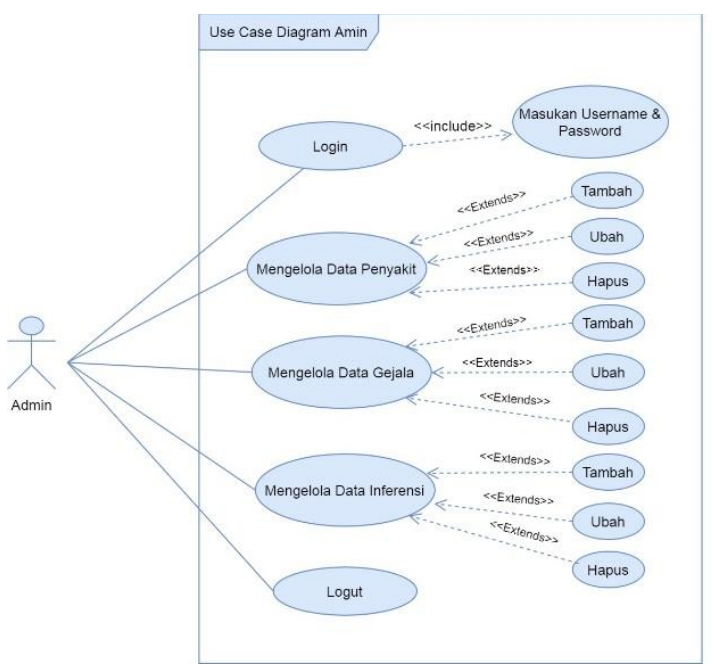

Gambar 2. Use Case Diagram Admin

Pada Gambar 2 terdapat beberapa fungsionalitas aplikasi diagnosa penyakit Tuberculosis yaitu:

a. Admin mempunyai hak akses login.

b. Admin mengelola data penyakit.

c. Admin dapat mengelola data gejala.

d. Admin dapat mengelola inferensi.

e. Admin dapat melakukan logout.

\subsection{Perancangan}

Pada perancangan basis data digambarkan tabel-tabel beserta relasinya menggunakan Entity Relationship Diagram (ERD) ditunjukkan pada Gambar 3.

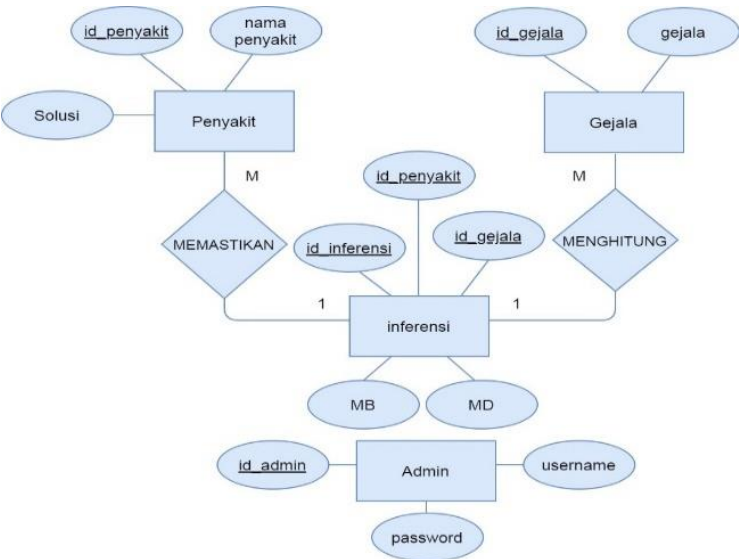

Gambar 3. ERD Aplikasi Diagnosa TBC
Pada Gambar 3 menunjukan ERD dari desain database aplikasi diagnosa TBC dengan tabel penyakit, gejala, inferensi, dan admin yang terdapat beberapa relasi.

\subsection{Implementasi}

A. User Interface User

1. Halaman Diagnosa

Tampilan halaman diagnosa penyakit Tuberculosis terdapat pada Gambar 4.

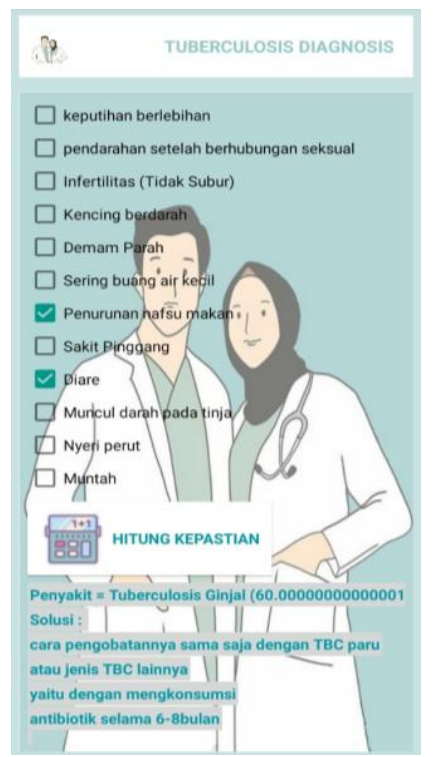

Gambar 4. Halaman Diagnosa

2. Halaman Informasi

Pada halaman informasi berisi deskripsi mengenai penyakit Tuberculosis dapat dilihat pada Gambar 5.

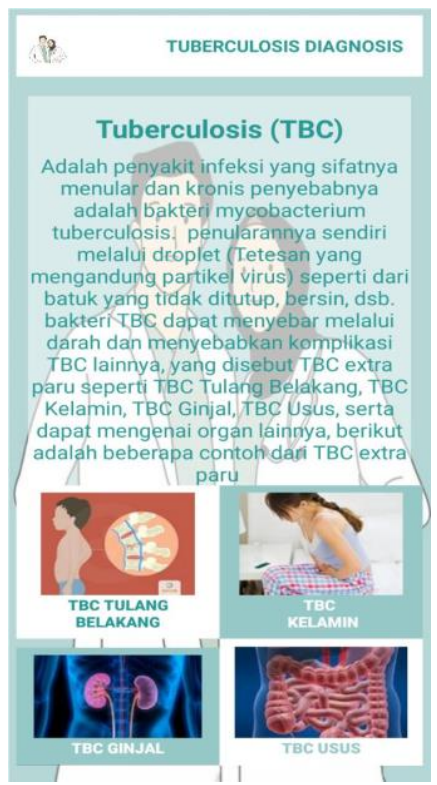

Gambar 5. Halaman Informasi 
3. Halaman About

Pada halaman ini terdapat deskripsi mengenai penulis yang dapat dilihat pada Gambar 6.

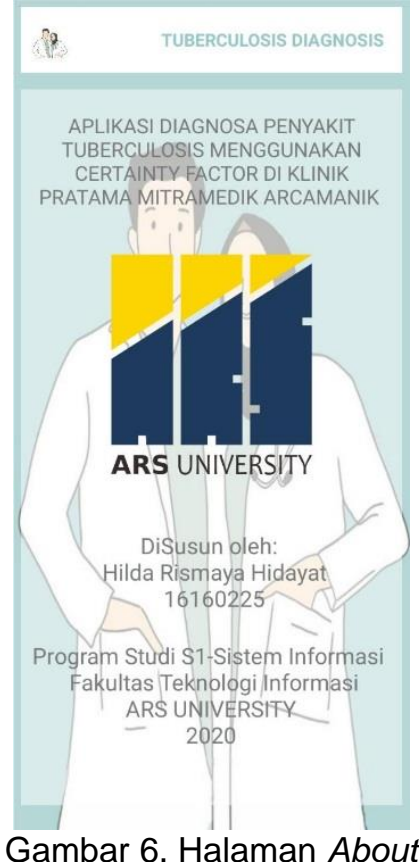

\section{B. User Interface Admin}

Halaman backend yang hanya dapat diakses oleh admin untuk mengelola data penyakit dapat dilihat pada Gambar 7.

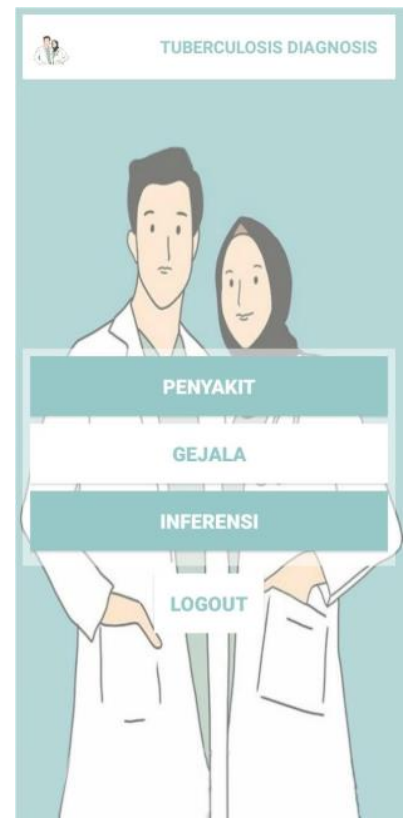

Gambar 7. Halaman Pengelola Data

\subsection{Pengujian}

Aplikasi yang akan dikembangkan pada penelitian ini akan diujikan menggunakan whitebox testing yang dapat dilihat pada Gambar 8.

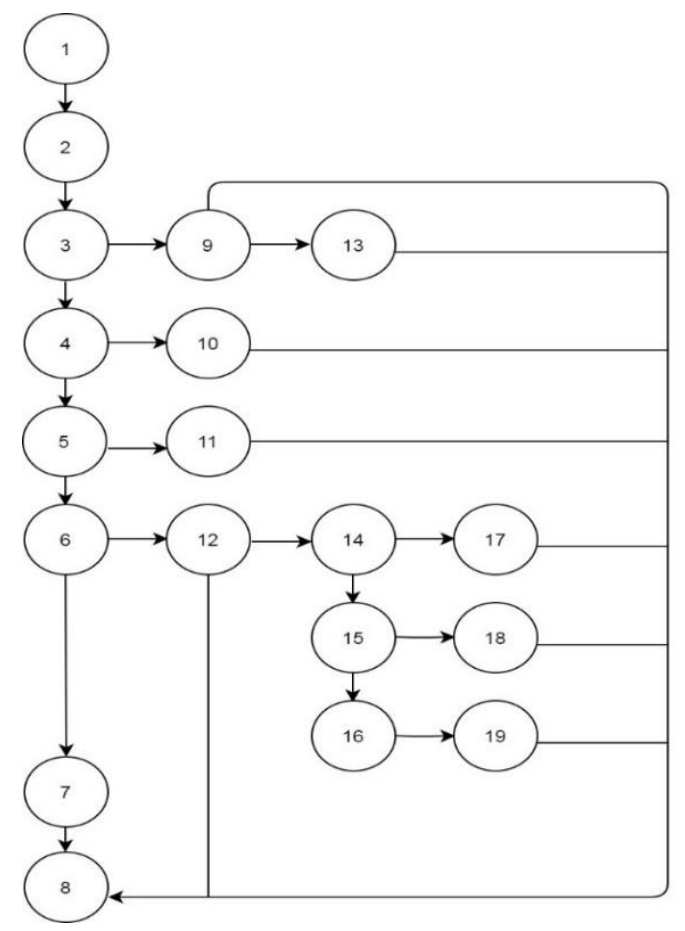

Gambar 8. Whitebox Testing

Kompleksitas siklomatis dari grafik alir untuk white box testing dapat diperoleh dengan perhitungan berikut ini:

\section{Dimana:}

$$
\mathrm{V}(\mathrm{G})=\mathrm{E}-\mathrm{N}+2
$$

$\mathrm{E}=$ Jumlah Edge yang ditentukan gambar panah.

$\mathrm{N}=$ Jumlah simpul grafik alir ditentukan dengan gambar lingkaran.

$\mathrm{V}(\mathrm{G})=26-19+2=9$

$V(G)<10$ berarti memenuhi syarat kekomplesitasi siklomatisnya.

\subsection{Support}

Perangkat yang digunakan untuk pemasangan aplikasi yang telah berhasil diujikan, serta menjelaskan kebutuhan hardware dan software standar yang akan digunakan untuk dapat menjalankan setelah usulan dapat dilihat pada Tabel 4 . 
Tabel 4. Spesifikasi Smartphone

\begin{tabular}{|c|c|c|}
\hline No. & $\begin{array}{l}\text { Kebutuhan } \\
\text { Smartphone }\end{array}$ & Keterangan \\
\hline 1 & $\begin{array}{l}\text { Operating } \\
\text { System }\end{array}$ & $\begin{array}{l}\text { Android Pie 9.0, } \\
\text { ColorOS 6.0.1 }\end{array}$ \\
\hline 2 & CPU & $\begin{array}{c}\text { Snapdragon 665, } \\
\text { octa-core, Adreno } \\
610\end{array}$ \\
\hline 3 & RAM & $8 \mathrm{~GB}$ \\
\hline 4 & Storage & $128 \mathrm{~GB}$ \\
\hline 5 & Konektivitas & $\begin{array}{c}\text { 4G LTE, Wi-Fi } \\
802.11 \mathrm{a} / \mathrm{b} / \mathrm{g} / \mathrm{n} / \mathrm{ac}\end{array}$ \\
\hline 6 & Layar & $\begin{array}{l}\text { IPS LCD } 6,5 \text { inci, } \\
720 \times 1600 \text { pixel }\end{array}$ \\
\hline
\end{tabular}

\section{Kesimpulan}

Penulis dapat menyimpulkan dari seluruh pembahasan pada bab-bab sebelumnya yang ada pada penelitian ini. Penulis berharap hasil dari penelitian ini dapat membantu masyarakat dalam memberi pengetahuan dan mendiagnosa mengenai penyakit Tuberculosis. Berikut kesimpulan dari sistem pakar diagnosa penyakit Tuberculosis:

1. Aplikasi sistem pakar diagnosa penyakit Tuberculosis ini telah memberikan infomasi tentang penyakit Tuberculosis tulang belakang, kelamin, ginjal dan usus, sehingga mempercepat penanganan medis kepada masyarakat.

2. Aplikasi sistem pakar ini mampu membantu masyarakat dalam mendiagnosa penyakit Tuberculosis secara dini. Hal ini dikarenakan terdapat fitur konsultasi mengenai penyakit Tuberculosis menggunakan metode Cerainty Factor sesuai anjuran dari pakar.

3. Aplikasi diagnosa penyakit Tuberculosis berhasil dibangun menggunakan pemrograman android dengan basis data SQLite.

Saran

Setelah penulis mengemukakan kesimpulan, penulis memberikan beberapa saran yang dapat membantu aplikasi sistem pakar ini dapat bekerja lebih optimal. Berikut saran-saran dari penulis Antara lain:

1. Menambahkan riwayat diagnosa agar user yang sudah pernah mendiagnosa tidak perlu mengisi gejala lagi untuk mendapatkan hasil diagnosa.

2. Penelitian selanjutnya diharapkan agar dilakukan perbandingan dengan metode inferensi yang lainnya. Hal tersebut memungkinkan untuk mencari perhitungan yang lebih akurat.

3. aplikasi yang dibangun untuk diagnosa penyakit Tuberculosis ini selanjutnya tidak hanya dikembangan pada sistem operasi android dengan Bahasa Java dan XML saja, namun dapat juga dikembangkan menggunakan Flutter yang dirilis oleh google dalam pengembangan aplikasi andoid dan iOS.

\section{Referensi}

Acton, Q. A. (2012). Pseudomonas: New Insights for the Healthcare Professional: 2012 Edition: ScholarlyBrief. ScholarlyEditions.

Andriani, A. (2016). Pemrograman sistem pakar. Yogyakarta: MediaKom.

Bangun, F. (2019). SISTEM PAKAR MENDIAGNOSA PENYAKIT TBC MENGGUNAKAN METODE TEOREMA BAYES. Jurnal Teknik Dan Informatika, 6(2), 23-29. http://jurnal.pancabudi.ac.id/index.ph p/Juti/article/view/674

Behl, R., O'Brien, J. A., \& Marakas, G. (2019). Management Information Systems (11th ed.). McGraw-Hill Education.

Chang, A. (2014). Pathology of the Medical Kidney, An Issue of Surgical Pathology Clinics, E-Book (Vol. 7, Issue 3). Elsevier Health Sciences.

Fanny, R. R., Hasibuan, N. A., \& Buulolo, E. (2017). RENALIS MENGGUNAKAN METODE CERTAINTY FACTOR DENGAN PENULUSURAN FORWARD CHAINING. 1(1), 13-16. https://www.ejurnal.stmik-

budidarma.ac.id/index.php/mib/articl e/view/316

Girsang, R. R., \& Fahmi, H. (2019). Sistem Pakar Mendiagnosa Penyakit Mata Katarak Dengan Metode Certainty Factor Berbasis Web. MATICS, 11(1), 27-31.

Hamer, D. H. (2010). Public health and infectious diseases. Elsevier.

Keith, L. G. (2012). Uncommon Infections and Special Topics (Vol. 2). Springer Science \& Business Media.

Laksono, G. D., Syaifidin, Y. W., \& Astiningrum, M. (2016). PENGEMBANGAN SISTEM PAKAR UNTUK MENDIAGNOSA INFEKSI SALURAN PERNAPASAN AKUT (ISPA) MENGGUNAKAN METODE 
CERTAINTY FACTOR. Seminar Informatika Aplikatif Polinema.

Lestyaningrum, A. D., \& Anardani, S. (2017). Rancang Bangun Sistem Pakar Diagnosa Penyakit Tuberkulosis (TBC) dengan Metode Forward Chaining. DOUBLECLICK: Journal of Computer and Information Technology, 1(1), 29-38. http://ejournal.unipma.ac.id/index.php/doubl eclick/article/view/1367

Mertaniasih, N. M. (2019). Buku Ajar Tuberkulosis Diagnostik Mikrobiologis. Airlangga University Press.

Paramitha, N., Junianto, E., \& Susanti, S. (2019). Penerapan Teorema Bayes Untuk Diagnosis Penyakit Pada Ibu Hamil Berbasis Android. Jurnal Informatika, 6(1), 53-61. https://doi.org/10.31311/ji.v6i1.4693

Putra, W. dian, Nugroho, P. .., \& Puspitarini, W. E. (2016). Game Edukasi Berbasis Android Sebagai Media Pembelajaran Untuk Anak Usia Dini. J I M P - Jurnal Informatika Merdeka Pasuruan, 1(1), 46-58. https://doi.org/10.37438/jimp.v1i1.7

Septiana, L. (2016). Perancangan Sistem Pakar Diagnosa Penyakit Ispa Dengan Metode Certainty Factor Berbasis Android. Jurnal Techno Nusa Mandiri, 13(2), 89-96.

Surya, R., Gunawan, D., Informatika, J., Teknik, F., \& Multimedia, U. (2018). Situsparu: Sistem Pakar Untuk Deteksi Penyakit Tuberkulosis Paru. http://ejournals.umn.ac.id/index.php/ TI/article/view/781

Wiguna, W., \& Alawiyah, T. (2019). Sistem Reservasi Paket Wisata Pelayaran Menggunakan Mobile Commerce di
Kota Bandung. Jurnal VOI (Voice Of Informatics), 8(2). 